PENGARUH SISTEM KARTEL

\title{
DALAM SISTEM PERDAGANGAN DI INDONESIA
}

\author{
Abdulah Safe'i \\ UIN Sunan Gunung Djati Bandung \\ abdulahsafei@uinsgd.ac.id \\ Jalaluddin \\ Ma'soem University \\ Jalaluddin_alafghani@yahoo.co.id
}

\begin{abstract}
ABSTRAK
Artikel ini berangkat dari fenomena banyaknya sistem kerjasama antar pengusaha yang secara sistemik mengatur dan menjalankan berbagai strategi demi tujuan dan keuntungan yang ditetapkan sedemikin rupa. Salah satu sistem kerjasama dimaksud adalah Kartel. Pada hampir setiap kegiatan ekonomi pangan, peluang terjadinya fenomena kartel selalu muncul. Selain karena kecenderungan perburuan rente di kalangan pelaku ekonomi yang tumbuh subur, fenomena kartel juga muncul karena lemahnya struktur penegakan aturan main, lemahnya pengawasan dan buruknya kualitas kebijakan ekonomi pemerintah secara umum. Bila dilihat dari cara memperoleh keuntungan, kartel pada dasarnya sama dengan praktek monopoli yang dilarang karena menimbulkan persaingan usaha yang tidak sehat. Hal tersebut mengacu adanya kerja sama antara perusahaan yang sejenis yang menimbulkan kerugian pada konsumen.
\end{abstract}

Kata Kunci: kartel, monopoli, konsumen, kebijakan ekonomi. 


\section{PENDAHULUAN}

Kartel menurut Kamus Besar Bahasa Indonesia adalah persetujuan sekelompok perusahaan dengan maksud mengendalikan harga komoditas tertentu. ${ }^{1}$ Ia juga dapat dikatakan sebagai kerjasama antara kelompok produsen pasar independen yang bekerja sama satu sama lain untuk meningkatkan keuntungan dan mendominasi pasar. Kartel biasanya merupakan asosiasi dalam bidang bisnis yang sama, dan merupakan aliansi para pesaing. Sebagian besar negara menganggap kartel sebagai perilaku anti persaingan, karena perilaku kartel mencakup penetapan harga hingga penurunan output. Kartel biasanya timbul dalam kondisi oligopoli dimana terdapat sedikit penjual dengan jenis produk yang homogen. Dengan adanya kartel, mereka dapat mengatur harga produk dengan cara membatasi ketersediaan barang di pasaran atau membagi wilayah penjualan. Di Indonesia, permainan kartel $^{2}$ ini semakin terkuak setelah Komisi Pemberantasan Korupsi (KPK) membongkar kasus suap yang berkaitan dengan impor da-

${ }^{1} \mathrm{KBBI}$ Offline 1.5.1

${ }^{2}$ Lihat https://kamus.tokopedia.com/k/kartel/. ging sapi. ${ }^{3}$ Komisi ini mengungkapkan, praktek serupa juga terjadi pada komoditas lain, seperti jagung, kedelai, beras, gula, dan terigu. Pengusaha bersama pejabat dan politikus memanfaatkan pembatasan impor pangan itu untuk mengeruk uang sebanyak-banyaknya.

Impor yang terbatas itu membuka peluang untuk mempermainkan harga. Inilah yang membuat harga daging di negara kita tidak wajar, bahkan paling tinggi di dunia. Bayangkan, daging sapi yang diimpor dari Australia harganya Rp 40 ribu, tapi di sini dijual hingga $\operatorname{Rp} 90$

\footnotetext{
${ }^{3}$ Kasus suap daging sapi impor adalah kasus suap di Indonesia yang terjadi pada awal 2013 terkait pengaturan kuota sapi impor menjadi 8000 ton. Tercatat uang sebesar 1,3 miliar digunakan untuk penyuapan yang akhirnya berujung pada hukuman penjara. Kasus ini melibatkan saksi yang berasal dari individu, pihak swasta dan pemerintah, mulai dari Elda Devianne Adiningrat, Thomas Sembiring, menteri pertanian Suswono bahkan hingga artis Ayu Azhari dan model Vitalia Shesya. Atas kasus tersebut KPK melakukan penyitaan sejumlah barang terkait kasus suap daging sapi impor. ${ }^{[1]}$

Setelah melalui berbagai rangkaian proses penyidikan, KPK kemudian menetapkan 5 orang sebagai tersangka. Mereka adalah Luthfi Hasan Ishaaq yang saat itu menjabat sebagai presiden Partai Keadilan Sejahtera dan anggota DPR periode 20092014, Ahmad Fathanah serta pihak Indoguna Utama yang terdiri dari Arya Abdi Effendi, Juard Effendi serta Maria Elizabeth Liman. Latar belakang sebagai presiden PKS dan perannya untuk mempengaruhi menteri pertanian Suswono plus kasus pencucian uang menjadikan Luthfi sebagai aktor utama dari kasus ini. Pun dengan Fathanah yang tersandung kasus pencucian uang. Alhasil keduanya menerima hukuman paling berat di antara semua tersangka, yakni hukuman penjara selama 16 tahun. $\stackrel{[2][3]}{[}$
} 
ribu. Dibandingkan dengan negara tetangga seperti Malaysia, harga daging sapi di Indonesia juga dua kali lebih mahal.

Laba yang dikeruk para pengusaha bisa mencapai puluhan triliun rupiah setiap tahun. Selama Januari-November tahun lalu (2012), misalnya, Indonesia mengimpor bahan-bahan pangan utama itu lebih dari 15 juta ton dengan nilai Rp 81,5 triliun. Ini yang menjelaskan pula kenapa importir daging sapi bersedia menyuap hingga miliaran rupiah buat mendapatkan kuota impor.

Di samping itu, pengusaha juga sering memanfaatkan momen lebaran dan liburan akhir tahun sebagai alasan untuk mendongkrak harga pangan sesuai keinginannya. Berita bencana yang kadang tak berhubungan pun tak jarang dimanfaatkan untuk tujuan yang sama. Kenaikan harga seolah menjadi ritual yang lebih pasti daripada jadwal hari raya itu sendiri.

Permainan kotor itu bisa dilakukan karena tak ada transparansi sekaligus akurasi soal data pangan, baik cadangan di dalam negeri maupun data impor. Sapi anakan dan indukan, bahkan piaraan yang digunakan untuk balapan atau membajak sawah, juga dihitung sebagai cadangan daging. Data impor daging sapi pun kerap ditutup-tutupi atau berbeda antara di lapangan dan di atas kertas. ${ }^{4}$

Dalam diskusi yang diselenggarakan Komisi Pemberantasan Korupsi (KPK) dengan tema 'Paparan Kajian Kebijakan Tata Niaga Daging Sapi Sebagai Komoditas Strategis' di Kantor KPK, Rabu (20/2/2013). Wakil Ketua KPK, Busyro Muqoddas mengatakan ada mafia kartel dalam perdagangan daging sapi di Indonesia. Populasi sapi potong di Indonesia berdasarkan data yang diperoleh KPK mencapai 93\%. Jumlah seharusnya dapat mencukupi kebutuhan daging dalam negeri. Tapi faktanya, pemerintah malah tetap melakukan impor daging sapi dari luar negeri seperti dari Australia. ${ }^{5}$

Berdasarkan kasus yang viral beberapa tahun yang lalu di atas, maka tulisan ini akan mencoba menganalisis tentang implikasi sistem kartel dalam sistem perdagangan di Indonesia. Namun, sebelum masuk pada pembahasan utama,

${ }^{4}$ http://www.surabayapost.co.id

${ }^{5}$ http://www.republika.co.id, diunduh pada tanggal 20 Februari 2013 
tulisan ini akan diawali terlebih dahulu dengan mendeskripsikan konsep kartel dan monopoli dalam perdagangan.

\section{Kajian Pustaka}

Kartel merupakan persekutuan antara beberapa badan usaha sejenis berdasarkan suatu perjanjian. Meskipun badanbadan usaha sejenis itu bergabung, namun masing-masing tetap memiliki kebebasan untuk mengurus badan usahanya sendiri-sendiri kecuali hal-hal yang telah disepakati dalam perjanjian persekutuan. ${ }^{6}$

Ada juga yang mendefinisikan kartel sebagai praktik perdagangan tidak sehat antara dua perusahaan atau lebih yang seharusnya bersaing tapi malah bekerja sama untuk mengendalikan harga agar sama-sama untung. Dengan mengatur pasokan, mereka bisa sama-sama menaikkan atau menurunkan harga barang sesuai kebutuhan. Yang menjadi korban adalah konsumen yang harus menanggung biaya di luar ongkos produksi tapi juga inefisiensi akibat kartel.7 Sedangkan dalam kamus istilah ekonomi populer,

${ }^{6}$ M. Tohar. Membuka Usaha Kecil. Hal. 82

${ }^{7}$ Kompas.com diunduh pada tanggal 14 Februari 2013 sistem kartel diartikan sebagai kerjasama yang saling menguntungkan antara beberapa pengusaha atau perusahaan, seperti dalam penentuan harga, jumlah, dan daerah pemasaran untuk membatasi persaingan antara mereka sehingga memperoleh semacam kedudukan yang bersifat monopoli. ${ }^{8}$

Lain halnya dengan monopoli, menurut Qardhawi monopoli adalah menahan barang untuk tidak beredar di pasar supaya naik harganya. ${ }^{9}$ Dari definisi tersebut dapat disimpulkan bahwa tindakan monopoli dilakukan atas dasar dorongan untuk mendapatkan laba maksimal. Orang yang melakukan monopoli, ia akan menetapkan harga sedemikian rupa sehingga dapat dilakukan penjualan dengan kuantitas kecil namun dapat memperoleh laba bersih yang lebih besar.

Sedangkan menurut Sadono Sukirno monopoli diartikan sebagai suatu bentuk pasar dimana hanya terdapat satu firma saja, dan firma ini menghasilkan barang yang tidak mempunyai barang pengganti

\footnotetext{
${ }^{8}$ Ralona M. Kamus Istilah Ekonomi Populer, hal. 136

${ }^{9}$ Qardhawi, Yusuf. Peran Nilai dan Moral dalam Perekonomian Islam (terjemahan), hal. 167
} 
yang sangat dekat. ${ }^{10}$ Biasanya keuntungan yang dinikmati oleh firma monopoli adalah keuntungan melebihi normal dan ini diperoleh karena terdapat hambatan yang sangat tangguh kepada firma-firma lain untuk memasuki industri tersebut.

Secara sunnatullah setiap perusahaan (termasuk perusahaan monopoli) akan berlaku hukum pertambahan hasil yang berkurang (the law of diminishing return), artinya dalam jumlah produksi tertentu perusahaan masih mengalami keuntungan, akan tetapi manakala produksi telah mencapai titik maksimal maka hasil yang diperolehnya justru akan menurun. Oleh karena itu, harga barang di pasar atau perusahaan monopoli dapat dipastikan selalu tinggi, karena sebagai akibat motif untuk memaksimalkan keuntungan. ${ }^{11}$

\section{Metodologi}

Adapun data ini diperoleh melalui penelitian literatur dan kajian teks (teks reading) dan selanjutnya dianalisis dengan menggunakan metode deduktif yang berangkat dari kaidah-kaidah

\footnotetext{
${ }^{10}$ Sukirno, Sadono. Pengantar Teori Mikroekonomi Edisi Kedua, hal 261

${ }^{11}$ Muhammad. Ekonomi Mikro dalam Perspektif Islam, hal 385
}

umum yang terdapat dalam Al-Qur'an dan Al-hadits tentang bisnis perdagangan dalam ekonomi Islam dan Undang-undang Nomor 5 Tahun 1999 tentang Larangan Praktek Monopoli dan Persaingan Usaha Tidak Sehat kemudian ditarik kesimpulan yang bersifat khusus yaitu sistem kartel dalam sistem perdagangan di Indonesia.

\section{PEMBAHASAN}

\section{Tinajauan Hukum Islam}

Hubungan manusia dengan Tuhan (Al-Tauhid) menempati kedudukan sentral dalam pandangan dunia Islam. Hubungan manusia dengan sesamanya dan dengan alam haruslah serasi dengan nilai-nilai yang telah ditetapkan oleh Allah. Segala yang ada, baik hidup maupun mati, melaksanakan suatu tujuan yang telah digariskan kepadanya oleh Allah, semua makhluk saling bergantung, dan segenap makhluk bergerak karena keserasian sempurna yang terdapat di antara bagian-bagiannya Allah berfirman dalam QS. Al-Qamar ayat 49:

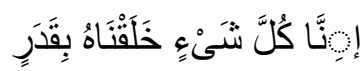


Artinya "Sesungguhnya Kami menciptakan segala sesuatu menurut ukuran." (QS. Al-Qamar: 49). ${ }^{12}$

Di antara hubungan manusia dengan Tuhannya merupakan syarat mutlak sebelum manusia itu berhubungan dengan sesamanya. Hubungan manusia dengan sesamanya merupakan hubungan sosial karena manusia saling membutuhkan antara yang satu dengan yang lainnya terutama disini dalam bidang ekonomi, pendekatan Islam berupaya mengatasi problem ekonomi lebih atas dasar ajaran moralnya dari pada legislasi. Salah satu dari berbagai aspek kehidupan manusia yang terikat dengan aturan-aturan hukum yang ada dalam Al-Qur'an adalah sistem muamalah, yang berkaitan dalam hal ini adalah syirkah.

Pada saat ini "persaingan" antara perusahaan sudah dianggap sebagai persoalan yang umum dan merupakan suatu hubungan yang tidak dapat dielakkan, karena setiap perusahaan akan memberikan yang lebih baik, berkualitas dan terjamin terhadap produknya bagi

12 Depag RI, Al-Qur'an dan Terjemahannya, hal. 883 konsumen. Akan tetapi, dengan adanya persaingan maka ada pihak-pihak yang akan dirugikan terutama pihak perusahaan yang kalah bersaing.

Kartel sama seperti halnya monopoli yang mempunyai posisi dominan dan kekuasaan untuk menentukan harga pasar, kartel di sini juga membahas mengenai bentuk pasar yang mengacu pada kerjasama antar perusahaan yang sejenis dengan menentukan ketetapan harga yang telah dibuat bersama. Kartel adalah tipe yang paling umum dari bentuk pasar, yang sekarang ini sedang merambah di Indonesia yang telah dilakukan oleh operator dalam bidang telekomunikasi. Kalau monopoli hanya penguasaan yang nyata atas suatu pasar bersangkutan oleh satu atau lebih pelaku usaha sehingga dapat menentukan harga barang dan atau jasa. $^{13}$

Tidak jauh berbeda dengan kartel, struktur pasar ini dicirikan oleh kerja sama perusahaan yang sejenis dengan mengadakan undang-undang tentang menentukan harga pasar. Adanya kerja sama tersebut menjadikan harga menjadi

\footnotetext{
${ }^{13}$ Abdul, R. Saliman, Hukum Bisnis, hal. 205
} 
naik lebih tajam, dan tidak adanya persaingan perusahaan satu dengan perusahaan lainnya dan ini menimbulkan kecurangan-kecurangan yang dilakukan oleh perusahaan yang telah bekerja sama dan akan mengakibatkan kerugian yang sangat besar bagi konsumen. Hal ini tidak sesuai dengan aturan hukum dan norma jual beli atau perdagangan yang terdapat dalam Al-Qur'an dan Al-hadist, sebagaimana firman Allah dalam QS. Mutaffifin ayat 2-7 :

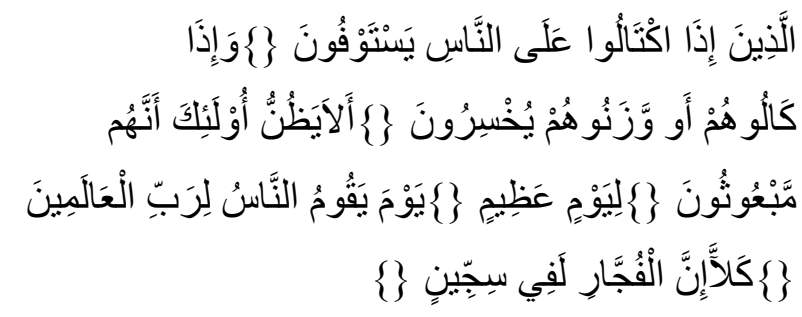

Artinya: "(Yaitu) orang-orang yang apabila menerima takaran dari orang lain mereka minta dipenuhi, dan apabila mereka menakar atau menimbang untuk orang lain, mereka mengurangi. Tidakkah orang-orang itu yakin, bahwa sesungguhnya mereka akan ibangkitkan, pada suatu hari yang besar, (yaitu) hari (ketika) manusia berdiri menghadap Tuhan semesta alam? Sekali-kali jangan curang, karena sesungguhnya kitab orang yang durhaka tersimpan dalam sijjin." (QS. Al-Mutaffifin: 2-7). ${ }^{14}$

Dengan demikian, persoalan muamalah merupakan suatu hal yang pokok dan menjadi tujuan penting dalam agama Islam dalam upaya memperbaiki kehidupan manusia. Oleh karena itu, syariah muamalah diturunkan oleh Allah dalam bentuk global dengan mengemukakan berbagai hukum dan norma yang dapat menjamin prinsip keadilan dalam bermuamalah sesama manusia.

Undang-Undang RI No. 5 Tahun 1999 memuat ketentuan kartel sebagai berikut: "Pelaku usaha dilarang membuat perjanjian, dengan pelaku usaha saingannya, yang bermaksud mempengaruhi harga dengan mengatur produksi dan atau pemasaran suatu barang dan atau jasa, yang dapat mengakibatkan terjadinya praktek monopoli dan atau persaingan usaha tidak sehat."15 Undang-Undang tersebut dikeluarkan untuk mengatasi terjadinya kartel yang bertujuan untuk mempengaruhi harga pasar, karena dengan adanya kartel maka timbullah suatu monopoli yang sangat

\footnotetext{
${ }^{14}$ Opcit, hal. 1035

15 Undang-Undang Anti Monopoli No.5 Tahun
} 1999, Pasal 11 
jelas dilarang dalam undang-undang perdagangan.

Kartel berperan meminimalisasi perang harga atau bersaing dalam harga, karena dari beberapa perusahaan telah menjalin kerjasama. Namun dampak dari adanya kerja sama ini atau kartel dapat mengakibatkan persaingan usaha yang tidak sehat dan juga berdampak pada kerugian konsumen. Pengambilan keputusan mengenai harga tergantung pada kesepakatan harga yang telah ditentukan bersama oleh perusahaan yang terkait, dan kebijakan yang diambil adalah memaksimalkan keuntungan, oleh karena itu masalahnya menjadi masalah monopoli.

Monopoli biasanya mengacu pada penguasaan terhadap penawaran dan harga. Monopoli dapat menentukan harga pasar untuk jenis barang produksinya. Karena ia produsen tunggal untuk jenis barang tertentu maka muncul motif untuk memaksimalkan keuntungan, ia akan menetapkan harga barang menurut kehendaknya dan menentukan agar penjualan suatu jumlah barang dengan harga tertentu untuk menghasilkan keuntungan bersih yang maksimum.

Ekonomi Islam menetapkan adanya monopoli dengan cara melihat perilaku individu, produsen dan penjual, ketika barang yang ditahan yang membahayakan kepentingan umum dengan tujuan untuk menaikkan harga, maka hal tersebut adalah monopoli yang tidak diperbolehkan oleh Islam, sama saja apakah perilaku tersebut timbul dari sektor khusus atau sektor umum, pemilik modal, atau serikat pekerja, sama juga monopoli berbeda-beda sesuai perbedaan tingkat monopoli.

Syirkah dalam fiqih muamalah merupakan ikatan kerja sama yang dilakukan dua orang atau lebih dalam perdagangan. Dengan adanya akad syirkah yang disepakati oleh kedua belah pihak, maka semua pihak yang mengikatkan diri berhak bertindak hukum terhadap harta serikat itu dan berhak mendapatkan keuntungan sesuai dengan persetujuan yang telah disepakati bersama.

Syirkah dan kartel mempunyai esensi yang sama yaitu menjalin kerja sama. Pandangan sebagian ulama terhadap 
syirkah ada yang memperbolehkan dan ada yang tidak tergantung dari tujuan kerja sama tersebut dan sebaliknya untuk kartel sendiri undang-undang melarang karena ada unsur monopoli. Sebagaimana telah dijelaskan di dalam Al-Qur'an bahwa setiap pedagang atau pengusaha muslim berkewajiban untuk mentaati seluruh aturan hukum dan norma jualbeli atau perdagangan yang terdapat dalam Al-Qur'an dan Al-hadits, serta pendapat para fuqaha', di antaranya adalah bahwa setiap pedagang atau pengusaha muslim dituntut untuk senantiasa berprilaku jujur dan adil serta menghindari segala bentuk persaingan yang curang dan kotor, sebagaimana firman Allah dalam QS. Huud ayat 85:

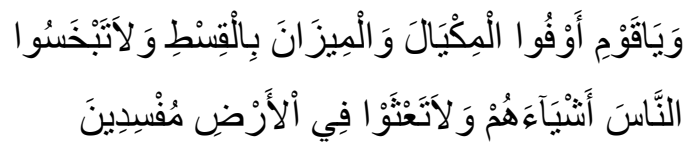

Artinya: "Dan Syu`aib berkata: "Hai kaumku, cukupkanlah takaran dan timbangan dengan adil, dan janganlah kamu merugikan manusia terhadap hak-hak mereka dan janganlah kamu membuat kejahatan di muka bumi dengan membuat kerusakan." (QS. Huud: 85). ${ }^{16}$

${ }^{16}$ Depag RI, Opcit, hal. 340
Masalah mu'amalah merupakan suatu hal yang penting dalam Islam dalam upaya memperbaiki kehidupan dan kesejahteraan manusia sebagaimana firman Allah dalam QS. Al-Qashash ayat 77 :

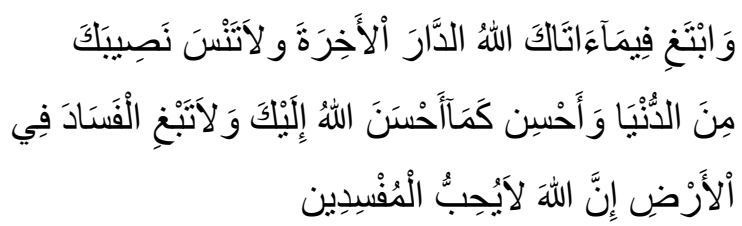

Artinya: "Dan carilah pada apa yang telah dianugerahkan Allah kepadamu (kebahagiaan) negeri akhirat, dan janganlah kamu melupakan bahagianmu dari keni’matan) duniawi dan berbuat baiklah (kepada orang lain) sebagaimana Allah telah berbuat baik kepadamu, dan janganlah kamu berbuat kerusakan di (muka) bumi. sesungguhnya Allah tidak menyukai orang-orang yang berbuat kerusakan." (Q.S. Al-Qashash). ${ }^{17}$

\section{Kebijakan Pemerintah}

Diberlakukannya Undang-Undang Nomor 5 Tahun 1999 tentang Larangan Praktek Monopoli dan Persaingan Usaha Tidak Sehat, dan dibentuknya Komisi Pengawas Persaingan Usaha (KPPU) sebagai lembaga yang bertugas untuk

${ }^{17}$ Ibid., hal. 623 
mengawasi pelaksanaan Undang-Undang tersebut, ${ }^{18}$ tidak dengan serta merta dapat menghilangkan segala bentuk praktek monopoli dan persaingan usaha tidak sehat yang selama ini ada, dan bahkan oleh sebagian kalangan di masyarakat telah dianggap sebagai suatu hal yang biasa. ${ }^{19}$

Pada hampir setiap sistem perekonomian, baik sistem yang berbau kapitalisme maupun sosialisme, pemerintah selalu memainkan peranan yang sangat penting. ${ }^{20}$ Dalam sebuah perekonomian yang modern, peran pemerintah dapat diklasifikasikan menjadi tiga katagori, yaitu:

a. Peran alokasi, yang maksudnya adalah pemerintah memiliki peran dalam mengalokasikan sumber-sumber ekonomi yang tidak dapat disediakan melalui sistem

18 Indonesia, Undang-Undang Tentang Larangan Praktek Monopoli Dan Persaingan Usaha Tidak Sehat, UU No.5, LN No.33 tahun 1999, TLN. No.3817, ps.30 ayat (1)

19 Lihat Ditha Wiradiputra, "Fenomena Persekongkolan," Mingguan Ekonomi dan Bisnis KONTAN. 1April 2002

20 A. Tony Prasentiantono, ed., Kebijakan Ekonomi Publik di Indonesia: Substansi dan Urgensi: Kumpulan Tulisan DR. Guritno Mangkoesoebroto, cet.1. hal.3. lihat juga Edy Suandi Hamid dan M.B. Hendrie Anto, Ekonomi Indonesia: Memasuki Milenium III, cet.1. hal. 91 pasar yang disebut sebagai barang publik, karena tidak ada pihak (non pemerintah) yang mau menyediakannya atau dapat juga dikatakan sistem pasar gagal mengakomodasikannya. Dan juga diharapkan dalam mengusahakannya oleh pemerintah agar alokasinya dilakukan secara efesien;

b. Peranan distribusi, maksudnya pemerintah sebagai alat pendistribusian pendapatan melalui instrumen yang dimilikinya;

c. Peranan stabilisator, maksudnya pemerintah mempunyai peranan sebagai stabilisator perekonomian. $^{21}$

Untuk melaksanakan peranannya tersebut, pemerintah memiliki kewenangan tertentu untuk mengatur dan mengarahkan kegiatan perekonomian sehingga dapat mendukung pelaksanaannya secara efektif, yaitu melalui pembuatan suatu kebijakan ekonomi. Namun demikian, peran pemerintah dalam perekonomian harus pula

\footnotetext{
${ }^{21} \mathrm{lbid}$, hal.5-10.
} 
didasarkan pada prinsis-prinsip yang jelas seperti:

a. Pemerintah harus berusaha untuk mencegah terjadinya monopoli usaha atau praktek-praktek kolusi di antara pengusaha oligopolis, yang dapat merugikan masyarakat;

b. Pemerintah harus mengatur dengan tegas masalah eksternalitas negatif yang dilakukan oleh sektor industri, yang dapat mengakibatkan alokasi yang salah (missed allocation) sumber-sumber ekonomi;

c. Pemerintah menguasai dan menjalankan cabang usaha yang menguasai hajat hidup orang banyak, dengan cara memanfaatkan BUMN sebaik-baiknya, agar dapat mengalokasikan sumber-sumber ekonomi seefesien mungkin;

d. Pemerintah harus selalu melakukan koreksi terhadap perilaku masyarakat (pengusaha dan konsumen), yang mempengaruhi pencapaian sasaran yang telah di tetapkan. ${ }^{22}$

Dalam pembuatan kebijakan ekonomi, pemerintah seyogyanya mendorong iklim berusaha yang sehat, efesien, dan kompetitif sehingga tercipta kesempatan yang sama bagi setiap warga negara untuk berpartisipasi di dalam proses produksi, pemasaran barang dan jasa. Namun yang terjadi terkadang justru sebaliknya, pemerintah malahan mendorong terjadinya iklim usaha yang tidak sehat, tidak efesian dan tidak kompetitif, melalui kebijakan ekonomi yang hanya menguntungkan orang dan kelompok tertentu saja.

Kebijakan pemerintah yang kurang tepat tersebut, mengakibatkan pasar menjadi terdistorsi. Terdistorsinya pasar mengakibatkan harga yang terbentuk di pasar tidak lagi merefleksikan hukum permintaan dan hukum penawaran yang riil. Kemudian, proses pembentukan harga dilakukan secara sepihak (misalkan oleh produsen) tanpa memperhatikan kualitas produk yang ditawarkan kepada konsumen.

${ }^{22}$ Ibid, hal.39 
Indonesia yang mengkalim diri sebagai negara kesejahteraan (welfare state) tentu wajib segera mengatasi fenomena persaingan usaha tidak sehat atau setidaknya menyembuhkan penyakit kegagalan pasar pada beberapa komoditas pangan strategis tersebut di atas. Jika kegagalan pasar ini dibiarkan terlalu lama, maka biaya sosial-ekonomi dan politik yang harus ditanggung masyarakat pasti lebih besar dan menimbulkan inefisiensi yang semakin akut.

Pertama, tidak ada alasan untuk tidak meningkatkan produksi, produktivitas, dan efisiensi usaha tani dan tata niaga komoditas pangan di hulu. Kinerja produksi pangan yang baik akan mengurangi dampak buruk dari sistem perdagangan tidak efisien, sampai batas tertentu. Perbaikan infrastruktur keras seperti jalan, jembatan, saluran irigasi perlu dilihat sebagai fixed variables untuk menunjang produksi pangan. Pembenahan sistem informasi harga, informasi pasar dan teknologi baru akan mengurangi inefisiensi sistem perdagangan atau tataniaga komoditas pangan di tingkat lapangan. Seluruh birokrasi pemerintah
Pusat, Pemerintah Provinsi dan Pemerintah Daerah wajib mewujudkan target besar swasembada produksi pangan dan efisiensi perdagangan ini.

Kedua, pembenahan administrasi perdagangan dalam negeri dan perdagangan luar negeri. Terlalu miris untuk mendengar fakta bahwa birokrasi pemerintah tidak mengetahui jumlah gudang pangan atau tidak memiliki data Tanda Daftar Gudang (TDG) dari pelaku usaha pangan. Setelah informasi gudang pangan dapat dikuasai, tentu arus pergerakan barang dari satu titik ke titik lain akan dengan mudah diestimasi, berikut fluktuasi harga yang terjadi. Administrasi data ini adalah cikal-bakal pencegahan praktik persaingan usaha tidak sehat, bahkan sampai pada penimbunan dan spekulasi harga yang menimbulkan dampak distortif.

Ketiga, peningkatan wibawa dan kapasitas lembaga pengawas persaingan usaha. Langkah ini dimulai dari tingkat dasar dan perbaikan pendidikan atau pemahaman tentang fenomena kartel dan kegagalan pasar ini. Apabila terdapat beberapa hambatan dalam penerapan 
pasal-pasal tertentu dalam UndangUndang Nomor 5 Tahun 1999 tentang Larangan Praktik Monopoli dan Persaingan Usaha Tidak Sehat, maka KPPU, Pemerintah dan Parlemen tidak harus merasa tabu untuk memperbaiki aransemen kelembagaan yang paling strategis tersebut.

KPPU sebagai lembaga yang bertugas mengawasi jalannya persaingan usaha juga bertugas mengawasi kebijakan/ peraturan pemerintah pusat atau daerah yang memberikan peluang kepada pelaku usaha untuk melakukan tindakan anti persaingan. Dan untuk menjadi perhatian kalangan khususnya di daerah adalah bahwa dengan diberlakukannya Undang-Undang Nomor 5 Tahun 1999, daerah pun turut berkewajiban untuk melaksanakan Undang-Undang Nomor 5 Tahun 1999 dan menciptakan iklim usaha yang sehat, efektif dan efesien, serta memberikan kesempatan yang sama bagi setiap warga negara untuk berpartisipasi di dalam proses produksi dan pemasaran barang atau jasa.

\section{SIMPULAN}

Dalam penelitian ini disimpulkan bahwa praktek kartel menurut UndangUndang RI No. 5 Tahun 1999 memuat pasal yang menjelaskan bahwa pelaku usaha dilarang membuat perjanjian, dengan pelaku usaha saingannya, yang bermaksud mempengaruhi harga dengan mengatur produksi dan atau pemasaran suatu barang dan atau jasa, yang dapat mengakibatkan terjadinya praktek monopoli dan atau persaingan usaha tidak sehat. Dengan demikian kartel merupakan usaha yang bertentangan dengan ekonomi Islam.

Untuk menghilangkan atau setidaknya mengurangi praktek kartel atau monopoli yang ada, hendaknya para penegak hukum melakukan tindakan tegas terhadap pelaku usaha tersebut sesuai dengan ketentuan hukum yang berlaku, sehingga peraturan atau undang-undang yang mengatur masalah monopoli dan persaingan usaha tidak sehat tidak hanya sekedar sebagai bacaan saja akan tetapi dijalankan sebagaimana mestinya. 
Hendaknya para pedagang atau tidak terjerumus ke dalam usaha-usaha pelaku usaha Muslim dalam bermua- yang merugikan masyarakat luas. Seperti malah senantiasa memperhatikan keten- kartel dan monopoli yang erat denagn tuan-ketentuan yang sudah ditetapkan kecurangan dan kedzaliman.

dalam hukum Islam sehingga mereka 


\section{DAFTAR PUSTAKA}

A. Tony Prasentiantono, ed. 1994. Kebijakan Ekonomi Publik di Indonesia: Substansi dan Urgensi: Kumpulan Tulisan DR. Guritno Mangkoesoebroto, cet.1. Jakarta: Gramedia Pustaka Utama.

Depag RI, Al-Qur'an dan Terjemahannya.

Ditha Wiradiputra, "Fenomena Persekongkolan," Mingguan Ekonomi dan Bisnis KONTAN. 1April 2002.

Edy Suandi Hamid dan M.B. Hendrie Anto. 2000. Ekonomi Indonesia: Memasuki Milenium III, cet.1. Yogyakarta: UII Press.

http://www.surabayapost.co.id

http://www.republika.co.id, di unduh pada tanggal 20 Februari 2013

Indonesia, Undang-Undang Tentang Larangan Praktek Monopoli Dan Persaingan Usaha Tidak Sehat, UU No.5, LN No.33 tahun 1999, TLN. No.3817, ps.30 ayat (1)

Kompas.com diunduh pada tanggal 14 Februari 2013

Muhammad. 2004. Ekonomi Mikro dalam Perspektif Islam. Yogyakarta: BPFE

M. Tohar. . Membuka Usaha Kecil.

Ralona M. 2006. Kamus Istilah Ekonomi Populer.

Sukirno, Sadono. 1995. Pengantar Teori Mikroekonomi Edisi Kedua. Jakarta: PT Raja Grafindo Persada.

Undang-Undang Anti Monopoli No.5 Tahun 1999, Pasal 11

Yusuf Qardhawi. 1997. Peran Nilai dan Moral dalam Perekonomian Islam (terjemahan). Jakarta: Rabbani Press. 
Abdulah Safe'i \& Jalaluddin 